\title{
Analyzing the Effect of Perceived Benefit of Loyalty Program towards Program Loyalty and Customer Loyalty (Case Study: Go-Points by Go-Jek)
}

\author{
Mochamad Lathoiful Kamal
}

\begin{abstract}
Go-Jek is one of the leading startup company in Indonesia that specialized in providing wide range of on-demand service, from ride-hailing to cleaning service. By the time, Go-Jek is growing fastly and now they have more than 40 million downloads on its app and 10 million weekly active users. With huge number of customers that spread across Indonesia, Go-Jek started to think to make their customers remain loyal since there are some competitors out there that will become a threat to the existing of Go-Jek customers. Therefore, Go-Jek launched its new feature called GoPoints that aims to establish long term relationship between Go-Jek and their customers. The purpose of this research is to analyze the relationship between perceived benefits of Go-Jek loyalty program (monetary savings, exploration, entertainment, recognition, and social benefits), program loyalty, and customer loyalty. A quantitative approach is applied by spreading online questionnaire to Go-Jek customers and collecting 400 responses. The results will be asses using confirmatory factor analysis and structural equation modeling. The findings revealed that all dimensions of perceived benefits of loyalty program have positive directions and significant influence in predicting program loyalty and customer loyalty. Entertainment benefits were found to be the most significant predictor of both endogen variables. Moreover, program loyalty was positively predicted customer loyalty.
\end{abstract}

Keywords-Customer Loyalty, Go-Jek, Loyalty Program, Perceived Benefits of Loyalty Program, Program Loyalty

\section{INTRODUCTION}

The growth of global economy that escalated over the past decades forces business players to increase their productivity which leads into competitive environment. This should be taken care seriously since there are many similar products and services that makes customer find difficulties to distinguish between their products out of competitor. In such a condition, it motivates the company to develop great strategy to meet customer desires in order to prevent from losing existing customer in efficient and innovative way. One of the strategy that companies try outsmart this intense rivalry is by maintaining their current customer through customer loyalty program (Bose \& Rao, 2011).

Nowadays, many firms use loyalty or frequency reward programs as their main marketing strategy to build a sustainable relationship with their customer. From airline to

Mochamad Lathoiful Kamal, Bandung Institute of Technology, Indonesia banking industry applied this strategy to keep their customer become loyal that leads into customer loyalty. It's because a loyal customer will come back and repurchase our products or services, increase their purchase value, and also spreading positive word of mouth that could affect in acquiring new customer (Zeithaml, Berry, \& Parasuraman, 1996). A research conducted by Boston Consulting Group (2014) shows that loyalty program could increase company's revenue up to $60 \%$. Another research said that an increase on customer retention rates by $5 \%$ could generates more than $25 \%$ increase in profit (Bain \& Company, 2001). This strategy is sufficiently proving that loyalty program could boost company's revenue. According to Amy Gallo (2014), maintaining existing customer is highly effective rather than acquiring a new one that can cost 5 to 25 times more expensive. Therefore, this strategy is favorable among industries from any sector because of the significant impact towards company performance.

Since customer loyalty program could be applied in any business industry, one of the fastest growing start-up company in Indonesia, Go-Jek, developed a loyalty program called GoPoints that aims to build a potential relationship with their customer and to turn them into a loyal one. Even though GoJek's CEO, Nadiem Makarim, claims that his company is leading amongst the competitors (Grab and Uber) by dominating 50 percent of Indonesia's ride-hailing market and 95 percent of food delivery service (Freischlad, 2017), it doesn't mean if Grab and Uber aren't trying to expand their market share as well. The competition between these three on demand providers become stiffer and intense since they try to penetrate the market by giving promotional discount generously in order to gain more customers. This is become a threat for Go-Jek regarding the customer characteristic of ridehailing industry is price-conscious (Yuniar, 2017), which means there are huge possibilities of customer that can switch into most beneficial on-demand provider.

As customer loyalty program, Go-Points expected to become the right strategy to retain Go-Jek existing customer. By giving point for each transaction using Go-Pay (Virtual Payment), customer could collect point as many as they can and redeem it to the desired reward such as voucher, discount coupon, free items, etc. Moreover, to trigger customer to collect more points, Go-Jek also give some prestigious 
products from smartphone to luxury car. The program designed as enticing as they can so the customer will perceive additional benefits by purchasing their services through this loyalty program. In the end, they will become satisfied and loyal customer. This research attempts to analyze the influence of perceived benefit that customer obtained from participate in loyalty program towards program loyalty as well as customer loyalty. Although previous studies have been conducted about this topic, most of it were focused on retailing industry. Besides, there are some questions remain the effectiveness of loyalty program such it might only follow the trend and waste of money. Furthermore, this research might be helpful for future research due to lack of references regarding analyzing of perceived benefit of customer loyalty program in Indonesia.

\section{LITERATURE REVIEW}

Dowling and Uncles (1997) stated that loyalty program is an essential tool in improving the overall value of the product or service as it will trigger the customer to make a repeat purchase in the future. Yi and Jeon (2003) define loyalty program as a marketing strategy that aimed to build customer loyalty by giving some benefits to profitable customers. According to Mimouni-Chaabane \& Volle (2010), perceived benefit of loyalty program can be defined as a value that program could offer and will perceived by its customer as benefits from participating in loyalty program. These benefits include of emotional responses for the enjoyment and pleasure feelings, motivation to get desired reward, and usage while redeeming the coupon (Mimouni-Chaabane \& Volle, 2010); (Meyer-Waarden, Benavent, \& Casteran, 2013). Lennheer et al. (2007) stated that customers have tendency to join loyalty program if they see opportunity of receiving additional benefits both financial and non-financial benefits.

Mimouni-Chaabane \& Volle (2010) categorized loyalty program benefits into three category which consists of utilitarian benefits, hedonic benefits, and symbolic benefits. Utilitarian benefits provide the customer with primary need and mostly associated with financial advantages. Efficiency and economical value are the key dimension of this benefit since it relates to basic motivation (Mimouni-Chaabane \& Volle, 2010). Monetary savings is the perfect example to illustrate utilitarian benefits since it's the most common benefit that attracting customer to join this program. Monetary savings can be in form of discount voucher and cash-back promo that members can obtain by continuously buying at the same provider.

Hedonic benefits are more subjective and abstract and also relates to pleasure and enjoyment feelings (Omar, Ramly, Alam, \& Nazri, 2015). These benefits are more preferred and effective compared to utilitarian benefits when it requires high involvement programs (Kivetz \& Simonson, 2002). MimouniChaabane \& Voll (2010) indicate two dimension of hedonic benefits which are exploratory and entertainment. Exploratory benefits can be exemplified by curiosity to trying new products, seeking for the latest information, and update with new the new trends. While collecting and redeeming points are the example of entertainment dimension. This is such an appealing program since it gives pleasure and self-fulfillment feelings benefits (Mimouni-Chaabane \& Volle, 2010).

The last one is symbolic benefits, intangible benefits of loyalty program that can fulfill customers need for social approval and recognition (Mimouni-Chaabane \& Volle, 2010). Symbolic benefits also can be referred as personal expression and personal identification (Omar, Ramly, Alam, \& Nazri, 2015). Mimouni-Chaabane \& Volle (2010) also classified symbolic benefits into two dimensions; Recognition and social benefits. Recognition benefits appear when members feel different from other customers by receiving special treatment such as extra attention or customized services for example priority check-in and exclusive lounges (Kim, Lee, Choi, Wu, \& Johnson, 2013). Social benefits can be experienced when loyalty program members consider themselves as part of exclusive group or top-priority customers. They have such a sense of belonging and share the same value with other members and company (Mimouni-Chaabane \& Volle, 2010).

According to $\mathrm{Yi} \&$ Jeon (2003), program loyalty is a customer positive attitude towards company's loyalty program. Program loyalty (attitudinal loyalty) can be defined as the willingness of a member to recommend, to use, and have strenght interest towards its loyalty program. Many previous studies show that program loyalty have positive association towards customer loyalty. For example, Meyer-Waarden (2008) discovered that most of cardholders have positive attitute towards the program since it gives them more benefits rather than non-members. The more benefits of loyalty program could offer, the higher possibility that customer would like to join the program (Leenheer, Heerde, H.A.Bijmolt, \& AleSmidts, 2007).

Dick and Basu (1994) explain that "Customer loyalty is viewed as the strength of the relationship between an individual's relative attitude and repeat patronage. The relationship is seen as mediated by social norms and situational factors. Cognitive, affective, and conative antecedents of relative attitude are identified as contributing to loyalty, along with motivational, perceptual, and behavioral consequences". Previous studies found that satisfied customers have a tendency to remain loyal to the company as long as the company stays to provide them with better service compared to the competitors (Bose \& Rao, 2011).

\section{CONCEPTUAL FRAMEWORK}

According to previous study, the researcher constructed the conceptual framework by adapting framework from Kim et al. (2013) which shows the relationship between perceived benefit of loyalty program, program loyalty, and customer loyalty and applied it on apparel retailing. The research model is presented in figure 1 . 


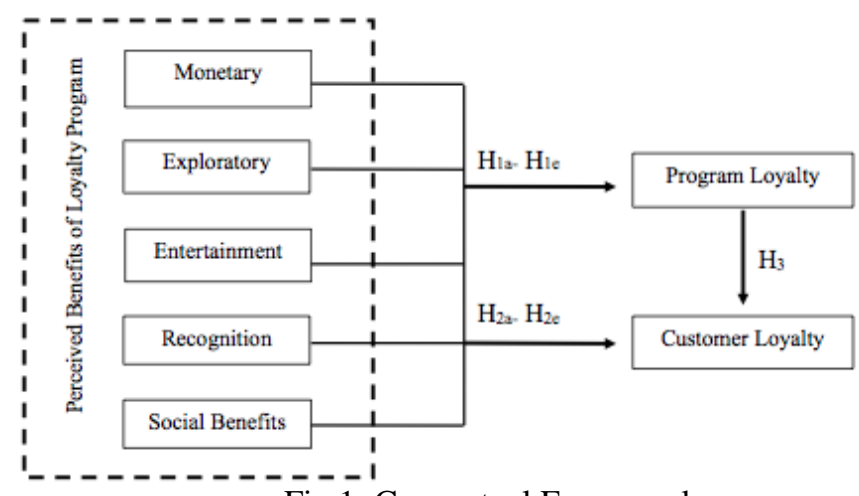

Fig 1: Conceptual Framework

\section{Methodology}

\section{A. Population and Sampling}

This research using quantitative method by spreading questionnaire to the respondents. The targeted population in this research is all of Go-Jek customer in Indonesia. There are no specific data regarding to the total number of Go-Jek customer so far, but we can assume it from the number of people who have been downloaded this app both for android and iOs platforms as alternative choice. As stated by Go-Jek CEO, Nadiem Makariem, at The Wall Street Journal's Live Asia conference in Hong Kong, he said that there are about 40 million downloads on Go-Jek app and he claimed it has around 10 million weekly active users in Indonesia (Freischlad, 2017). Thus, based on his statement, the author speculates that the total number of Go-Jek customer is between 10 to 40 million customers across Indonesia.

In this research, the researcher will use judgment sampling method which parts of non-probability sampling designs. Judgement sampling is used because the respondent should meet the author's criteria to answer the research question. So, each member of population does not have the same probability to be chosen as the sample subjects. The respondent's criteria for this study are people who have already used Go-Jek services and involve in Go-Points program actively. Since this research will use structural equation model as analysis technique and the researcher choose maximum likelihood estimation method, the minimum number of sample required is five until ten times from total indicators tested (Ferdinand, 2005). Which means 24 indicators multiplied by 10 is 240 respondents. Hair (2010) also found that the ideal number of sample required for structural equation model is between 100 until 200 samples. Moreover,To determine the sample size of this study, the researcher use table of sample size provided by Krejci and Morgan (1970) with 95\% confidence level and 5\% of error tolerance. Based on the table, for number of population is higher than 1.000 .000 , the sample size needed for this research is only 384 respondents and sums up to 400 respondents in order to be more relevant in return.

\section{B. Data Analysis Technique}

Pilot test was conducted using SPSS software in order to examine the validity and reliability of the questionnaire before spread it extensively and as much as 41 respondents were tested. The validity test performed by comparing the Pearson Correlation or r-statistic result with the r-table and its considered valid if the result exceed the r-table (Ghozali, 2005). Reliability test was performed using Cronbach's Alpha theory and the variable considered reliable if the reliability coefficient score is higher than 0.7 (Sekaran, 2003).

The next step is confirmatory factor analysis and structural equation model using LISREL software. This analysis technique used to solve multilevel models simultaneously that cannot be resolved by path analysis model on a linear regression equation. Confirmatory factor analysis aims to ensure data validity and reliability while structural equation model aims to know to see the effect, significant level from each effect size, prove hypothesis, as well as assess the model fit.

\section{V.RESULTS}

According to the pilot test, all of data and variable tested were found to be considered as valid and reliable since the data results exceed the critical point which has been set. For respondents' demographic results, the data gathered shows that female respondents are dominating this research (60.5\%). Respondents' ages range from $<17$ years to $>31$ years with $41 \%$ between $17-21$ years old followed by $33 \%$ of $22-26$ years old. Slightly more than half of the respondents were students or college students (56\%) and dominated by respondents who lives in JABODETABEK area (Jakarta, Bogor, Depok, Tangerang, Bekasi) with percentage of $56 \%$ as well. Most of respondents have monthly income less than IDR 2.000.000 which is as much as 215 people or cover $54 \%$ of the total respondents. Moreover, the respondent's frequency in using Go-Jek service is $2-4$ times a week (45\%) and spent around IDR 50.001 - IDR 100.0000 within a week (51\%).

Table 1 provides the overview of validity and reliability results based on confirmatory factor analysis. It shows that all of indicators can be considered as valid because all of loading factors $(\lambda)$ exceed the critical point which is 0.5 (Hair, 2010). The findings also show that all of indicators can be considered as reliable because all of the construct (latent variable) have a value of Construct Reliability (CR) greater than 0.7 and Variance Extracted (AVE) greater than 0.5.

The next step in data analysis is structural equation modeling and was conducted using the maximum likelihood estimation method to the hypotheses. According to the results on table 2 below, the structural model exhibits a good fit which means that the overall model tested are fit with sample data. The results of the study also found that all of program benefits have positive predictors for program loyalty and customer loyalty. It is because all of the standardized results show positive direction as well as t-value results that exceed the critical point 1.96 which means there is significant impacts. Therefore, both hypothesis 1 and 2 are acceptable.

This research is in line with Yi and Joen's (2003) which also found that benefits gained from joining in a loyalty 
TABLE I

VALIDITY AND RELIABILITY CFA

\begin{tabular}{|c|c|c|c|c|c|c|}
\hline $\begin{array}{c}\text { Latent } \\
\text { Variable }\end{array}$ & $\begin{array}{l}\text { Manifest } \\
\text { Variable }\end{array}$ & $\lambda$ & $\lambda^{2}$ & e & CR & AVE \\
\hline \multirow{3}{*}{ MS } & MS1 & 0.742 & 0,551 & 0,449 & \multirow{3}{*}{0.783} & \multirow{3}{*}{0.546} \\
\hline & MS2 & 0.767 & 0,588 & 0,412 & & \\
\hline & MS3 & 0.706 & 0,498 & 0,502 & & \\
\hline \multirow{3}{*}{ ELY } & ELY1 & 0.906 & 0,821 & 0,179 & \multirow{3}{*}{0.858} & \multirow{3}{*}{0.673} \\
\hline & ELY2 & 0.89 & 0,792 & 0,208 & & \\
\hline & ELY3 & 0.637 & 0,406 & 0,594 & & \\
\hline \multirow{3}{*}{ ENM } & ENM1 & 0.576 & 0,332 & 0,668 & \multirow{3}{*}{0.786} & \multirow{3}{*}{0.557} \\
\hline & ENM2 & 0.857 & 0,734 & 0,266 & & \\
\hline & ENM3 & 0.777 & 0,604 & 0,396 & & \\
\hline \multirow{4}{*}{$\mathrm{RCN}$} & RCN1 & 0,772 & 0,596 & 0,404 & \multirow{4}{*}{0.903} & \multirow{4}{*}{0.701} \\
\hline & RCN2 & 0,888 & 0,789 & 0,211 & & \\
\hline & RCN3 & 0,920 & 0,846 & 0,154 & & \\
\hline & RCN4 & 0,757 & 0,573 & 0,427 & & \\
\hline \multirow{3}{*}{ SB } & SB1 & 0,728 & 0,530 & 0,470 & \multirow{3}{*}{0.85} & \multirow{3}{*}{0.654} \\
\hline & SB2 & 0,839 & 0,704 & 0,296 & & \\
\hline & SB3 & 0,854 & 0,729 & 0,271 & & \\
\hline \multirow{3}{*}{ PLY } & PLY1 & 0,789 & 0,623 & 0,377 & \multirow{3}{*}{0.83} & \multirow{3}{*}{0.621} \\
\hline & PLY2 & 0,859 & 0,738 & 0,262 & & \\
\hline & PLY3 & 0,708 & 0,501 & 0,499 & & \\
\hline \multirow{5}{*}{ CLY } & CLY1 & 0,877 & 0,769 & 0,231 & \multirow{5}{*}{0.914} & \multirow{5}{*}{0.682} \\
\hline & CLY2 & 0,840 & 0,706 & 0,294 & & \\
\hline & CLY3 & 0,865 & 0,748 & 0,252 & & \\
\hline & CLY4 & 0,756 & 0,572 & 0,428 & & \\
\hline & CLY5 & 0,783 & 0,613 & 0,387 & & \\
\hline
\end{tabular}

program should influence loyalty behavior positively. Among all of program benefits, entertainment benefits have the greatest influence for explaining both of program loyalty and customer loyalty. Given that entertainment benefits refer to the means of enhancing customer experience in participating this loyalty program with excitement and enjoyment. This result is similar with study from Bose and Rao (2011) whose claimed that entertainment benefits is directly predicted both program loyalty and customer loyalty yet contradicts with Mattila (2006) and Kim et al. (2013) research which found that benefits involving point redemption are may necessary but not significantly effect to loyalty intentions.

Further explanation that could relate with the findings is on the age of respondents involved which is dominated by millennials (age between 17-37). A prior study underlined that millennials are more likely to perceive a higher level of hedonic benefits rather than older generations since they tend to spend their time on entertainment activities such as watching movies, social media, and playing video games (Carpenter \& Moore, 2009). This result might support the fact that Go-Point program offers excitement feeling in form of mini games which is swipe the token to get the point and it is well-delivered. Moreover, Koneva (2017) said that collecting points is suitable for business that demand high frequency purchase from the customer and Go-Jek business model suits with its loyalty program since most of the customer are using Go-Jek service more than 4 times a week.

The other benefits that has the significant influence in predicting program loyalty and customer loyalty is monetary savings benefits. Customer tend to loyal to the program if they receive any economic benefits in terms of discount (Kim et al. 2013). Besides, known that Indonesian customer characteristic are prefer promotional discount rather than tangible reward and actively seeking for it (Prihtiyani, 2012). It is mainly because Indonesia is categorized as developing country which the citizens have low income. Thus, they tend to respond monetary savings strategy enthusiastically during the current economic condition. This finding supports study from Omar (2015), Kim et al. (2013), and Mimouni-Chaabane \& Volle (2010) yet contradict Dowling and Uncle's (1997) who said that price reduction is the least useful rewards in building loyalty intention because it only generates short-term effect to the customer.

Social benefits also have the significant influence in explaining program loyalty and customer loyalty. This finding is similar with Kim et al. (2013) and claimed that this benefit could help the company to create or strengthen their relationship with their loyalty program members by building a sense of community belonging that leads into adding value in the program itself. It is because millennials tend to like brands that align with their values, needs and preferences (White, 2017). Another benefit that observed in this research is exploratory benefits. This benefits also has positive relationship in predicting program loyalty and customer loyalty. Exploratory benefits might lead into loyalty because of the opportunity to explore another product which leads 
TABLE II

STRUCTURAL EQUATION MODELLING RESULT

\begin{tabular}{|c|c|c|c|c|}
\hline \multirow{2}{*}{\multicolumn{2}{|c|}{ Endogenous Construct }} & \multicolumn{3}{|c|}{ Structural Model } \\
\hline & & Standardized & \multicolumn{2}{|r|}{ T-Value } \\
\hline \multicolumn{2}{|c|}{ Program Loyalty } & \multicolumn{3}{|l|}{$R^{2}=0.849$} \\
\hline $\mathrm{H} 1 \mathrm{a}$ & Monetary Savings & \multicolumn{2}{|l|}{0.241} & 4.767 \\
\hline $\mathrm{H} 1 \mathrm{~b}$ & Exploratory & \multicolumn{2}{|l|}{0.187} & 4.268 \\
\hline $\mathrm{H} 1 \mathrm{c}$ & Entertainment & \multicolumn{2}{|l|}{0.284} & 5.941 \\
\hline H1d & Recognition & \multicolumn{2}{|l|}{0.232} & 4.183 \\
\hline H1e & Social Benefits & 0.277 & & 4.252 \\
\hline \multicolumn{2}{|c|}{ Customer Loyalty } & \multicolumn{3}{|l|}{$\mathrm{R}^{2}=\mathbf{0 . 9 2 0}$} \\
\hline $\mathrm{H} 2 \mathrm{a}$ & Monetary Savings & \multicolumn{2}{|l|}{0.124} & 2.763 \\
\hline $\mathrm{H} 2 \mathrm{~b}$ & Exploratory & \multicolumn{2}{|l|}{0.135} & 3.682 \\
\hline $\mathrm{H} 2 \mathrm{c}$ & Entertainment & \multicolumn{2}{|l|}{0.249} & 5.42 \\
\hline $\mathrm{H} 2 \mathrm{~d}$ & Recognition & \multicolumn{2}{|l|}{0.224} & 4.803 \\
\hline $\mathrm{H} 2 \mathrm{e}$ & Social Benefits & \multicolumn{2}{|l|}{0.119} & 2.147 \\
\hline $\mathrm{H} 3$ & Program Loyalty & \multicolumn{2}{|l|}{0.34} & 3.384 \\
\hline \multicolumn{2}{|r|}{ Fit Statistics (N=400) } & Recommended Value & Results & Conclusion \\
\hline \multicolumn{2}{|c|}{ Normed Chi-Square ( $\left.\chi^{2} / \mathrm{df}\right)$} & $2<\chi^{2} / \mathrm{df}<5$ & 3.244 & Good Fit \\
\hline \multicolumn{2}{|r|}{ CFI } & 0.9 & 0.977 & Good Fit \\
\hline & NNFI & 0.9 & 0.972 & Good Fit \\
\hline & RMSEA & $<0.10$ & 0.075 & Good Fit \\
\hline & RFI & 0.9 & 0.96 & Good Fit \\
\hline & PNFI & $0-1$ & 0.809 & Marginal Fit \\
\hline & PGFI & $0-1$ & 0.666 & Marginal Fit \\
\hline
\end{tabular}

into the increase of purchase intention. Moreover, according to Zimmerman (2017), millennials are known to have sense of exploration and seek for new experience. They have a tendency for trying new product to fulfill their curiosity. Besides, Go-Jek also has various of service offered that make exploratory benefits might have a significant influence towards loyalty behavior.

Finally, the other loyalty program benefits that has significant influence towards program loyalty and customer loyalty is recognition benefits. According to the research results, recognition benefits has the lowest value in predicting program loyalty yet the second in contributing customer loyalty. It means that recognition benefits may be well necessary in building customer loyalty, but not a sufficient condition in building program loyalty. The reason why this condition might occur it is because millennials tend to be loyal if they get a customized or personalized treatment from the brand. They want to stick longer towards the brand if the company is paying attention to their specific needs and creating the impression that they are is a special customer (Kaye, 2014)

However, in terms of program loyalty to customer loyalty, this research finding is also similar with study from Yi \& Jeon (2003), Kim et al. (2013), and Omar (2015) who also found the positive influence of program loyalty in predicting customer loyalty. Which means that, if the customer are remains loyal to the loyalty program that they participate in, the consumer will become more loyal to the brand itself other than competitors. Thus, it is important for the business owner to maximize the effectiveness of the program since it is genuinely influence the customer loyalty that leads into the increase of sales as well. In short, hypothesis 3 is accepted.

\section{CONCLUSION}

This study examines the effects of perceived benefits of loyalty program towards program loyalty and customer loyalty within the context of on-demand service provider, Go-Jek. Moreover, this study also analyzed the relationship among variables. After the research has been conducted, researcher able to answer the research question that stated on chapter one. The results revealed that perceived benefits of loyalty program have positive effect on predicting program loyalty and customer loyalty. From five benefits that have been analyzed, all of them have positive influence towards loyalty and entertainment benefits were found to have the most significant 
influence in predicting them. Moreover, program loyalty also predicting the customer loyalty. It can be seen from the variables tested that these variables have positive effect on building customer loyalty. Therefore, business owners should concern about all of the benefits that they could give to its customer through loyalty program since it leads to loyalty intention which means increasing the company revenue as well.

\section{LIMITATION AND FURTHER RESEARCH}

This study has several limitations that are used as consideration for further research. First, the research scale measurement was adjusted from Mimouni-Chaabane \& Volle (2010) and it was applied within the context of retailing sector. It may not fully have captured perceived benefits of loyalty program from other business model such as on-demand service provider tries to offers. Moreover, it was applied within the context of French customers, it might not have the same characteristic as Indonesian customers. Second, the variables that are used in this study are limited (perceived benefits of loyalty program, program loyalty, and customer loyalty). Adding the variables are needed to explore factors that influence loyalty intention such as company performance. The indicators might be related to pricing and promotion strategy, service quality offered, and brand image. Lastly, the object of this study is limited to on-demand service provider, thus giving generalization limitations of the research results. Further research can be done on other objects such as airline industry, e-commerce, restaurant, et cetera.

\section{REFERENCES}

[1] S. Bose and V. G. Rao, "Perceived Benefits Of Customer Loyalty Programs: Validating The Scale In The Indian Context," Management \& Marketing Challanges for the Knowledge Society, vol. 6, no. 4, pp. 543-560, 2011.

[2] V. A. Zeithaml, L. L. Berry and A. Parasuraman, "The Behavioral Consequences of Service Quality," The Journal of Marketing, 1996. https://doi.org/10.2307/1251929

[3] Boston Consulting Group, "Leveraging the Loyalty Margin: Rewards Programs That Work," 21 April 2014. [Online]. Available: https://www.bcgperspectives.com/content/articles/retail_transportation _travel_tourism_leveraging_loyalty_margin_rewards_programs_work/ \#chapter1. [Retrieved 11 November 2017].

[4] Bain \& Company, "Prescription for Cutting Costs," September 2001. [Online]. Available: http://www.bain.com.

[5] A. Gallo, "The Value of Keeping the Right Customers," 29 October 2014. [Online]. Available: https://hbr.org/2014/10/the-value-ofkeeping-the-right-customers. [Retrieved 11 November 2017].

[6] N. Freischlad, "Go-Jek is Beating Uber and Grab," 9 June 2017. [Online]. Available: https://www.techinasia.com/gojek-beating-ubergrab. [Retrieved 13 November 2017].

[7] R. W. Yuniar, "What Uber Needs to Do to Catch Up with Asian Rivals," 31 July 2017. [Online]. Available: http://www.scmp.com/week-asia/business/article/2103900/what-uberneeds-do-catch-asian-rivals. [Retrieved 13 November 2017].

[8] G. R. Dowling and M. Uncles, "Do Customer Loyalty Programs Really Work?,"Sloan Management Review, vol. 38, no. 4, pp. 71-82, 1997.

[9] Y. Yi and H. Jeon, "Effects of Loyalty Programs on Value Perception, Program Loyalty, and Brand Loyalty," Journal of the Academy of Marketing Science, June 2003.

https://doi.org/10.1177/0092070303031003002
[10] A. Mimouni-Chaabane and P. Volle, "Perceived Bene ts of Loyalty Programs: Scale Development and Implications for Relational Strategies," Journal of Business Research, pp. 32-37, 2010. https://doi.org/10.1016/j.jbusres.2009.01.008

[11] L. Meyer-Waarden, C. Benavent and H. Casteran, "The Effects of Purchase Orientations on Perceived Loyalty Programmes' Benefits and Loyalty," International Journal of Retail \& Distribution Management, vol. 41, no. 3, pp. 201-225, 2013.

https://doi.org/10.1108/09590551311306255

[12] J. Leenheer, H. J. Heerde, T. H.A.Bijmolt and AleSmidts, "Do loyalty programs really enhance behavioral loyalty? An empirical analysis accounting for self-selecting members," International Journal of Research in Marketing, vol. 24, no. 1, pp. 31-47, March 2007. https://doi.org/10.1016/j.ijresmar.2006.10.005

[13] A. Ferdinand, Structural Equation Modeling Dalam Penelitian Manajemen, Aplikasi Model-Model Rumit Dalam Penelitian Untuk Tesis Magister and Disertasi Doktor, Semarang: Baand Penerbit Universitas Diponegoro, 2005.

[14] U. Sekaran, Research Method For Business: A Skill Building Approach, vol. 4, John Wiley \& Sons, Inc, 2003.

[15] J. J. Hair, Multivariate Data Analysis, vol. 7th, Pearson Prentice Hall, 2010.

[16] H.-Y. Kim, J. Y. Lee, D. Choi, J. Wu and K. K. P. Johnson, "Perceived Benefits of Retail Loyalty Programs: Their Effects on Program Loyalty and Customer Loyalty," Journal of Relationship Marketing, vol. 12, no. 2 , pp. $95-113,2013$

https://doi.org/10.1080/15332667.2013.794100

[17] R. V. Krejcie and D. W. Morgan, "Determining Sample Size for Research Activities," Educational and Psychological Measurement, vol. 30, pp. 607-610, 1970. https://doi.org/10.1177/001316447003000308

[18] I. Ghozali, Aplikasi Analisis Multivariate Dengan Program SPSS, Semarang: Baand Penerbit Universitas Diponegoro, 2005.

[19] A. Mattila, "How affective commitment boosts guest loyalty (and promotes frequent-guest programs)," Cornell Hotel and Restaurant Administration Quarterly, vol. 47, no. 2, pp. 174- 181, 2006. https://doi.org/10.1177/0010880405283943

[20] J. Carpenter and M. Moore, "Utilitarian and hedonic shopping value in the US discount sector," Journal of Retailing and Consumer Services, vol. 16, no. 1, pp. 68-74, 2009.

https://doi.org/10.1016/j.jretconser.2008.10.002

[21] A. Koneva, "10 Loyalty Programs to Encourage Your Customers to Make More Purchases," September 2017. [Online]. Available: https://www.ecwid.com/blog/10-loyalty-programs.html. [Retrieved Februaty 2018].

[22] E. Prihtiyani, "Konsumen Lebih Suka Diskon Dibandingkan dengan Hadiah,” July 2012. [Online]. Available: http://ekonomi.kompas.com/read/2012/07/26/16575799/Konsumen.Le bih.Suka.Diskon.Dibandingkan.dengan.Hadiah. [Retrieved February 2018].

[23] G. R. Dowling and M. Uncles, "Do customer loyalty programs really work?," Sloan Management Review, pp. 71-82, 1997.

[24] B. White, "How to inspire loyalty in maturing millennials," 13 November 2017. [Online]. Available: http://www.marketinginteractive.com/how-to-inspire-loyalty-in-maturing-millennials/. [Retrieved 11 February 2018].

[25] K. Zimmerman, "How Millennials Are Creatively Approaching Their Business Travel," 6 June 2017. [Online]. Available: https://www.forbes.com/sites/kaytiezimmerman/2017/06/06/howmillennials-are-being-creative-with-their-travel/\#48e432018a89. [Retrieved 11 February 2018].

[26] D. Kaye, "Marketing to Millennials? Make It Personal and Customized.," 3 July 2014. [Online]. Available: https://www.entrepreneur.com/article/234891. [Retrieved 11 February 2018]. 